\title{
METAPHORICAL CONCEPT “BODY” \\ IN THE SACRED PENTATEUCH TEXTS OF THE ENGLISH BIBLE
}

\author{
Ganna Izyumtseva \\ Senior Lecturer, National Pedagogical Dragomanov University, Ukraine \\ e-mail: avizyumtseva@gmail.com,orcid.org/0000-0002-5604-8391
}

\section{Summary}

The aim of the paper is to determine the content and structure of a basic metaphorical concept BODY identified in the Pentateuch texts of the English Bible. The nature and mechanism of the metaphorical concept is considered in the light of recent linguo-metaphorological investigations with the emphasis on distinction between the notions of "metaphorical concept" and "conceptual metaphor". The method used in the research includes procedures of the analysis of metaphorical concepts elaborated by Yu.V. Kravtsova within the semantic- cognitive approach to study of metaphors and modelling of metaphorization. As a result, first, the composition of the content of the metaphorical concept at the semantic and cognitive levels of its stratification was established; second, the identified cognitive features were structurized according to their significance within a given ethno-culture; the third, the hierarchy of senses relevant for the concept bearers was revealed. Overall, the conducted analysis has offered a fresh insight into the author-specific conception of reality as a human body, in its various forms and manifestations.

Keywords: usual metaphor, occasional metaphor, representative, associates, qualifier.

$$
\text { DOI https://doi.org/10.23856/4305 }
$$

\section{Introduction}

For almost half of a century there has been unfading interest among linguists in issues connected with different aspects of the concept: its origins, evolution, acquiring the status of a mental unit, and others. The string of works devoted to the research of this structure is overwhelming, it "grows at an exponential rate" (Vorkachev, 2011: 65). Nevertheless, the recent investigations of metaphorical concepts have proven that a multifaceted phenomenon of "concept" is yet (if ever) to be fully comprehended.

In their seminal work "Metaphors we live by", G. Lakoff and M. Johnson introduced the notion of "metaphorical concept" as a notion equivalent to a notion of "conceptual metaphor" (Lakoff \& Johnson, 2003: 6). Since then, in the works of some scholars, such as A.P. Chudinov, D.Ye. Ertner, I.M. Kobozeva, and some others, the dividing line between these notions has remained blurred allowing the researchers to use them interchangeably. However, recent linguo-metaphorological investigations have proven that metaphorical concepts are formations other than conceptual metaphors with distinctive characteristics of their own (Cherkhava, Homyak, Majkowski, 2020; Kravtsova, 2014). The study of these formations becomes a fresh and promising topic of conceptual research. It allows the researcher to penetrate into the language-reasoning depth, and to look at the phenomena of language through the lens of figurative analogue and associative relations revealing the reality that may otherwise remain hidden or lost.

The present paper aims at determining the content and structure of a basic metaphorical concept BODY of the Pentateuch. 


\section{Objectives:}

- to enhance the distinctive features of the metaphorical concept;

- to introduce the methodological foundation of the study;

- to describe the content and structure of a basic metaphorical concept BODY of the Pentateuch.

The research is conducted on material of the Pentateuch texts of the "The Orthodox Study Bible. The St. Athanasius Academy of Orthodox Theology", namely: "Genesis" (Gn.), "Exodus" (Ex.), "Numbers" (Nu.), "Deuteronomy" (Deut.). The choice of material for investigation is conditioned by the need for further comprehensive semantic-cognitive research of fideistic discourse in general and the Pentateuch texts of the English Bible in particular.

\section{2. "Metaphorical concept" and "conceptual metaphor"}

Although it is impossible to fully describe the peculiarities of the metaphorical concept and the conceptual metaphor within the scope of this paper, yet to sketch out their nature and mechanism seems reasonable and important. Let us first dwell on the phenomenon of conceptual metaphor.

It worth noting that regardless of some innovative developments and revisions of the theory of conceptual metaphor, in the past forty years, the core of the definition of the conceptual metaphor has remained the same. According to G. Lakoff, the metaphor is a fundamental cognitive mechanism that organizes human thinking and language. The conceptual metaphor, in its turn, is "a cross-domain mapping in the conceptual system" (Lakoff, 1993: 203). Its essence consists in comprehension of one thing in terms of something else. In the Biblical metaphor God is Father, for example, God is experienced in terms of earthly father-children relations that evokes a range of different meanings. Just few of them are that God takes care of, feeds, protects, and chastens us (His children), like earthly father does. Thus, in conceptual metaphor two conceptual domains or "domains of experience" (Kövecses, 2018; Lakoff, 1993) are activated. The elements and relations of a less familiar conceptual domain (a target domain) are "asymmetrically" (Croft, Cruse, 2004: 196) mapped onto a more familiar conceptual domain (a source-domain). The latter one is structured by a system of frames (scenarios, slots, concepts) (Chudinov, 2003: 71). Importantly, these mappings, that is to say, conceptual metaphors are fixed within a linguistic and cultural tradition of ethnos (Baranov, 2014:32). Although we believe that such metaphors as, for instance, God is Father, Rock, Fire, Healer, Creator, and others ought to gain the status of trans-ethnic, because they cross far over the boundaries of one ethnic group. In addition, in the light of the above discussed, it is important to keep in mind that G. Lakoff by stressing the cognitive character of the metaphor has made a distinction between conceptual and language metaphors thereby relegating language metaphors to position of derivatives of the metaphor in thought (Steen, 2011: 28). This tenet entails that language metaphors are possible only because they exist "in thought".

Like conceptual metaphors, as Yu.V. Kravtsova has shown in detail, metaphorical concepts are mental formations. Indeed, they are the core units of the metaphorical (conceptual) image of the world which integrates figurative analogue and associative conception of the world. However, in contrast with the conceptual metaphor, which is the metaphor by itself, the metaphorical concept (hereafter MC) is a mental construct explicated by metaphors. It is the general figurative conception that reflects stable in the collective and individual consciousness figurative analogue and associative relations of realities, and is objectified via a string of metaphors. Thus, the MC can be simply viewed as a figurative-mental paradigm, a system of 
metaphorical variants (with their usual and occasional metaphorical meanings) of a particular figurative-mental invariant (Kravtsova, 2014: 96-98). For instance, in the texts of the Pentateuch, the metaphors face, countenance, fatness, mouth, hand, foot/feet, finger, foreskin, legs are representatives, that is to say, metaphorical variants of the figurative-mental invariant, that is MC BODY (the face of the ground, the fatness of the earth, the mouth of their seed, the hand of God, the finger of the Lord, etc.).

Importantly, by analogy with the concept in general, we distinguish between content and structure of the MC. The content of the MC along with verbalized cognitive characteristics (associates) includes its usual and occasional metaphorical realizations (nominative representatives). A structure of the $\mathrm{MC}$ is arranged according to the kernel-periphery principle and reflects the hierarchy of senses. In particular, the associations that are the most salient in the consciousness of the bearers of a MC constitute its nucleus and the area around the nucleus. The peripheral zone incorporates individually significant cognitive characteristics (Kravtsova, 2014: 55, 96-98). Overall, a metaphorical concept fixes and at the same time reveals the collective ethnic-specific figurative analogue and associative conception of reality refracted through individual figurative consciousness of its bearer.

Thus, all afore-said demonstrates the need to make a distinction between conceptual metaphors and metaphorical concepts. Metaphorical concepts are complex mental formations that reflect stable in the collective and individual consciousness figurative analogue-associative relations, and are explicated via metaphors in a process of creative verbal activity of their bearers.

\section{The method and techniques}

To examine the basic metaphorical concepts of the Pentateuch, we adopted the procedures elaborated by Yu.V. Kravtsova within the semantic-cognitive approach to metaphor investigation. In this reserch, basic metaphorical concepts are understood as those that are objectified by a considerable number of metaphorical nominations. Identification of basic metaphorical concepts is performed by establishing all metaphorical contexts of the Pentateuch texts with their subsequent elucidation in order to ascertain which exactly basic metaphorical concepts the discovered metaphorical nominations realize. For instance, the results of the Pentateuch metaphorical contexts examination demonstrated the presence of a basic MC BODY. The metaphorical nominations that explicate its presence are face, eyes, mouth, back, countenance, hand, arm, foot/feet, leg, finger, fatness, foreskin. In the Pentateuch, when this MC reflects the author's figurative idea of different manifestations of objects\phenomena, we find it objectified as the metaphors face, countenance, eyes, hand, back, finger mouth, foreskin. Indeed, the consequences of such manifestations can be terrifying ( $I$ will set My face against that soul who eats blood and will utterly destroy him from among his people (Lev. 17:10), or bringing protection and support (the Lord lift up His countenance upon you (Nm. 26:6); the Lord brought us out of Egypt with a mighty hand and an outstretched arm (Deut. 6:21), You stretched out Your right hand; The earth swallowed them up (Ex. 15:12)). In addition, the MC BODY is explicated in association with observable front surface (the face of the ground (Gn. 1:8)), location in space (at the foot of the mountain (Ex. 19:17)), fruitfulness of the earth (the fatness of the earth (Gn. 27:28)), etc.

Subsequent analysis of discovered basic metaphorical concepts, according to Yu.V. Kravtsova, implies seven steps: 1) specifying usual (fixed in the dictionaries) figurative meanings; at this stage, the absence of regular labelling of figurative senses in both American 
and British dictionaries complicates the analysis; 2) establishing and interpreting occasional metaphorical meanings; 3) identification of cognitive features of metaphorical projection on the basis of component analysis of all representatives of the MC and cognitive interpretation of semes; their subsequent description in terms of associates and their qualifiers according to hyperonymo-hyponymic relations; 4) verification of established cognitive features by means of semantic-cognitive metaphorical modelling; this allows determining a common semantic-cognitive feature that undergirds metaphorization and is a qualifier of the associate (for instance, the model "human physiological characteristics $\rightarrow$ terrestrial objects form": the submodel "parts of a human body $\rightarrow$ a piece of land contour": the whole face of the earth (Gn. 1:6)); 5) description of the MC content at the semantic (usual-metaphorical and occasional-metaphorical sublevels) and cognitive (associative-metaphorical) levels; 6) ranking the identified cognitive features (associates) by the degree of frequency and the nature of manifestation; description of the analyzed MC structure in terms of its nuclear, around-nuclear zone, and periphery (Kravtsova, 14: 274).

Thus, the above seven-step technique of the MC analysis reveals the structure and content of a MC, allows the researcher to establish the hierarchy of figurative senses relevant for representatives of a particular linguo-culture and refracted through the lens of the author's specific consciousness.

\section{Results and discussion}

The findings of undertaken analysis of the Pentateuch texts have allowed identification of the following basic metaphorical concepts VOICE, CHARACTER, BODY, PLANT EMOTIONS, DESIRE, LIFE, LOVE, and FIRE. This paper will focus on examination of the content and structure of the MC BODY.

As our research has shown, the content of the MC BODY is formed by the following representatives and associates:

I. Semantic level (metaphorical representatives):

1. The usual figurative meanings sublevel (usual metaphorical meanings): face, countenance, hand larm, mouth, eye, legs, fatness.

Face. 1. Front (Strong, 1996: 691), somebody's presence (Mounce, 2009: 231; Strong, 1996: 691).

Countenance. Turning the countenance toward someone means showing the favour (Mounce, 2009: 141).

Hand/Arm. Strength, power, sovereignty, mercy, provision, and justice (Mounce, 2009: 317).

Mouth. 1. Speech, edge (Strong, 1996: 486). 2. Opening of things (Mounce, 2009: 458).

Eye. 1. A fountain (Strong, 1996: 473). 2. Someone's attitude toward or judgement of a person or situation (Mounce, 2009: 230).

Legs. The furniture support (Mounce, 2009: 263).

Fatness. 1. The best part of something (Mounce, 2009:242). 2. Abundance (Strong, 1996:350).

2. The occasional metaphorical meanings interpretation: face, mouth, back, eyes, hand, arm, countenance, finger, foreskin, fatness, foot/ feet, legs.

Face. 1. Observable exterior surface (front): the face of the ground (Gn. 1:8). 2. Someonelsomething's manifested presence, strongly revealed in a response to something $\backslash$ somebody: I will set My face against that soul who eats blood (Lev.17:10); I will forsake them and turn 
My face from them (Deut. 31:17). 3. Somebody $\backslash$ something's manifested essence, personality: There shall be no different gods before My face (Deut. 5:7); the Lord make His face shine upon уои (Nu. 6:25).

Mouth. 1. The same as speech (unveilingldisclosing something): but by every word proceeding from the mouth of God man shall live (Deut. 8:3); forgotten... from the mouth of their seed (Deut. 31:21). 2. Something abruptly opened and shut: by opening its mouth the earth shall swallow them down $(\mathrm{Nu} .16: 30) ; 3$. The rounded opening to a hollow space: they would roll the stone from the well's mouth (Gn. 29:3), the mouth of his sack (Gn. 42:27).

Back. Somebody $\backslash$ something partially manifested: I will take away My hand, and you shall see My back (Ex. 33:23).

Eyes. Opinion, judgment: "Lord," he said, “if I have found favor in Your eyes" (Ex. 34: 9).

Hand. Somebodylsomething's strength and power manifested: I will stretch out My hand and strike the Egyptians with all My wonders (Ex 3:20); The sanctuary, O Lord, which Your hands established (Ex. 15:17).

Arm. The same as hand: the Lord brought us out of Egypt with a mighty hand and an outstretched arm (Deut. 6:21).

Countenance. The same as face 3: the Lord lift up His countenance upon you (Nu. 6:26).

Finger. Divine power in action, manifested (Ryken et al., 1998): He gave him two tablets of testimony, tablets of stone, written with the finger of God (Ex. 31:18); the sorcerers said to Pharaoh, "This is the finger of God" (Ex. 8:14).

Foreskin. Obstinacy, tenacious unwillingness to yield (manifested): circumcise the foreskin of your heart (Deut. 10:16).

Fatness. Something characterized by excellence and surplus: the fatness of the earth (Gn. 27:28).

Foot/feet. 1.The lower end (part) of somebody or something: they stood at the foot of the mountain (Ex. 19:17); Under His feet was, as it were, a paved work of sapphire stone (Ex. 24: 10).

Legs. The lower extension of something functioning as support: legs of a table (Ex. 25:23, 26).

The most frequently used metaphor: face (45 cases).

II. Cognitive level (associates) of the MC BODY:

1. The object manifestation:

1) the object disclosure: 'partial' (see My back, but My face shall not be seen)),'complete (as for a man)' (before My face, the Lord make His face shine upon, the Lord lift up His countenance);

2) the object disclosure in response to something $\backslash$ somebody: 'strong reaction' (I will set My face against that soul, I will ...turn My face from them);

3) realization: 'expressed ability' (I will stretch out My hand and strike the Egyptians; the Lord brought us out of Egypt with a mighty hand and an outstretched arm; Your hands establish; I have found favor in Your eyes);

4) activity: 'action' (the mouth of God, the mouth of their seed, the finger of God);

5) intensity: 'tenacious resistance' (the foreskin of your heart).

2. Dynamics:

movement: 'something abruptly opened and closed' (opening its mouth the earth; the earth, which has opened its mouth).

3. Form:

geometry of object: 'the top front boundary' (the whole face of the earth; the face of the ground), 'rounded' (the well's mouth; the mouth of his sack the mouth of Hahiroth). 
4. Form\Function: 'the extension bearing the weight of another thing'.

5. Quantity/Value: 'much larger than is needed', 'having the most positive qualities' (the fatness of the earth);

6. Correlation: location: 'the lowest part, bottom' (the foot of the mountain, under His feet). Verification of established cognitive features by semantic-cognitive metaphorical modelling:

1) "human physical characteristics $\rightarrow$ terrestrial objects form": the sub-model "parts of a human body $\rightarrow$ a piece of land contour": the whole face of the earth (Gn. 1:6); the face of the ground (Gn. 1:8); the mouth of Hahiroth (Nu. 33:7);

2) "human physical characteristics $\rightarrow$ God the object manifestation": a) the submodel "parts of a human body $\rightarrow$ God $>$ in response to something $\backslash$ somebody": I will set My face against that soul who eats blood (Lev. 17:10); b) the submodel "parts of a human body $\rightarrow$ God> the object disclosure (partial\complete)": the Lord lift up His countenance upon you ( $\mathrm{Nu}$. 6:26); the Lord make His face shine upon you (Nu. 6:25); I will take away My hand, and you shall see My back (Ex. 33:23); c) the submodel "parts of a human body $\rightarrow$ God > realization": Your right hand, O God, dashed the enemy in pieces (Ex. 15: 6); I will stretch forth My hand and smite you (Ex. 9: 14), "Lord," he said, "if I have found favor in Your eyes (Ex. 34: 8); d) the submodel "parts of a human body $\rightarrow$ God> activity": Then the sorcerers said to Pharaoh, "This is the finger of God" (Ex. 8:14), The sanctuary, O Lord, which Your hands established (Ex. 15:17); by every word proceeding from the mouth of God man shall live (Deut. 8:3);

3 ) "human physical characteristics $\rightarrow$ atmospheric phenomenon> form": the submodel "parts of a human body $\rightarrow$ condition of the atmosphere> contour": the face of heaven's firmament (Gn. 1:20);

4) "human physical characteristics $\rightarrow$ terrestrial objects〉 dynamics": the submodel "parts of a human body $\rightarrow$ a piece of land movement (presencelabsence)": opening its mouth the earth (Nu. 16:30); the earth, which has opened its mouth (Gn. 4:11);

$5)$ the model "human physical characteristics $\rightarrow$ household items form": a) the submodel "parts of a human body $\rightarrow$ container> contour": the mouth of his sack (Gn. 42:27);

$6)$ the model "human physical characteristics $\rightarrow$ buildings form": the submodel "parts of a human body $\rightarrow$ constructions > contour": would roll the stone from the well's mouth, water the sheep, and put the stone back in its place on the well's mouth (Gn. 29:3, 8, 10);

7) the model "human physical characteristics $\rightarrow$ physical characteristics of plants the object manifestation": the submodel "parts of a human body $\rightarrow$ parts of plants activity": from the mouth of their seed (Deut. 31:21);

8 ) the model "human physical characteristics $\rightarrow$ God> correlation": the submodel "personal appearance $\rightarrow$ God> spatial location": under His feet (Ex. 24: 10);

9) "human physical characteristics $\rightarrow$ human mental characteristics $>$ the object manifestation": the submodel "parts of a human body $\rightarrow$ human inner parts intensity": the foreskin of your heart (Deut. 10:16);

$10)$ the model "human physical characteristics $\rightarrow$ terrestrial objects tion": the submodel "personal appearance $\rightarrow$ a piece of land > a great deal $\backslash$ positive evaluation": the fatness of the earth (Gn. 27:28);

$11)$ the model "human physical characteristics $\rightarrow$ terrestrial objects> correlation": the submodel "personal appearance $\rightarrow$ a piece of land spatial location": the foot of the mountain (Ex. 19:17);

$12)$ the model "human physical characteristics $\rightarrow$ household items form/function": a) the submodel "parts of a human body $\rightarrow$ devices contour, function": legs of a table (Ex. 25:23, 26). 
Thus, the content of the MC BODY includes the following representatives and associates:

1. Semantic level: legs, fatness;

1) the usual figurative meanings sublevel: face, countenance, hand, mouth, eyes, arm,

2) the occasional metaphorical meanings interpretation: face, mouth, back, eyes, hand, arm, countenance, finger, foreskin, fatness, foot/feet, legs.

2. Cognitive (associative-metaphoric) level:

'the top front boundary'; 'strong reaction'; 'action of unveiling $\backslash$ disclosing something'; 'partial disclosure'; 'complete disclosure (as for a man)'; 'rounded and hollow'; 'abruptly opened and closed'; 'much larger than is needed'; 'having the most positive qualities'; 'expressed ability'; 'tenacious resistance'; 'the lowest part, bottom', 'vertical part of something bearing its weight'.

The ranking of the identified cognitive features (associates) revealed the following:

- the nuclear zone is constituted by associates with the qualifiers: "the object manifestation (realization)" - $37 \%$; "form 'geometry of an object'- $31 \%$ ";

- the around-nuclear zone is constituted by associates with the qualifiers: "the object manifestation (the object disclosure)" - 14\%;

- the peripheral zone is constituted by associates with qualifiers: "the object manifestation (the object disclosure in response to something $\backslash$ somebody)" $-6 \%$, "the object manifestation (activity)" - $4 \%$, "the object manifestation (intensity)" $-1 \%$, "correlation (location in space)" - 3\%, "dynamics (movements (presencelabsence))"- $2 \%$, "quantity/value (much larger than is needed)/(having the most positive qualities)" - $1 \%$, "function ("vertical part of something bearing its weight')" $-1 \%$.

As we can see, the MC BODY structure is organized in the following way:

- the nuclear zone includes associates with the qualifiers "the object manifestation (realization)" and the "form (geometry of an object)";

- the around-nuclear zone includes associates with the qualifiers "the object manifestation (the object disclosure)";

- the peripheral zone includes associates with qualifiers "the object manifestation (the object disclosure in response to something $\backslash$ somebody, activity, intensity)"; "correlation (location in space)"; "dynamics (movements (presencelabsence))"; "quantity/value (much larger than is needed/having the most positive qualities)", "function ("vertical part of something bearing its weight')"'.

\section{Conclusions}

As the findings have shown, at the semantic level, the content of the MC BODY is represented by the usual figurative meanings (face, countenance, mouth, eyes, hand, arm, fatness, legs) and the occasional metaphorical meanings (face, mouth, back, eyes, hand, arm, countenance, finger, foreskin, fatness, foot/feet, legs). At the cognitive (associative-metaphoric) level, the following cognitive features (associates) are found: 'the top front boundary'; 'strong reaction'; 'action of unveiling $\backslash$ disclosing something'; 'partial disclosure'; 'complete disclosure (as for a man)'; 'rounded and hollow'; 'abruptly opened and closed'; 'much larger than is needed'; 'having the most positive qualities'; 'expressed ability'; 'tenacious resistance'; 'the lowest part, bottom', 'vertical part of something bearing its weight'.

As far as the MC BODY structure, for the author of the Pentateuch, the most salient associations (the nuclear and around-nuclear zone) are qualified as "the object manifestation 
'realization' (37\%)", the "form 'geometry of an object' (31\%"), and "the object manifestation 'the object disclosure' (14\%). The peripheral zone includes associates that are qualified as various "object manifestations" ('the object disclosure in response to something $\backslash$ somebody' (6\%), 'activity' (4\%), 'intensity' (1\%)"), "correlation (3\%)", “dynamics (2\%)", and "quantity/value (1\%)", "function (1\%)".

Importantly, among metaphorical representatives of the MC BODY, the metaphor face (45 cases) is the most frequently observed. It can be explained, first of all, by the fact that the face is a part of a human body used to detect and identify the individual. As a result, the face of a person is often associated with a person himself. Secondly, a face is the observable front surface of a human body that is not stone-still, but, like the water or land surface, constantly changes its expression and colour palette. In our view, it is this specificity of a human face that has become the motivating metaphorical characteristics for the author of the Pentateuch, and explains the prevailing number of the metaphor face among other representatives of the MC BODY.

Thus, the conducted analysis has allowed identification and description of the structure and content of the MC BODY. It reflects the author-specific conception of reality as a human body, in its various forms and manifestations.

Prospects for future research are to analyze the rest of the basic concepts of the Pentateuch and to determine the metaphorical conceptosphere of the author of the sacred texts. Taking in consideration the origin of the Pentateuch, such task seems promising.

\section{References}

Baranov A. N. (2014). Deskriptornaya teoriya metafory (The descriptive theory of metaphor). Moscow: LRC Publishing House. (in Russian)

Cherkhava, O., Homyak, M., \& Majkowski, W. (2021). METAPHORICAL CONCEPT - THE BEDROCK OF HUMAN BEING. Scientific Journal of Polonia University, 40(3), 17-22. https://doi.org/10.23856/4002

Chudinov A. P. (2003). Metaforicheskaya mozaika v sovremennoy politicheskoy kommunikatsii (Metaphorical Mosaic in Modern Political Communication). Ekaterinburg: Ural State Pedagogical University Press. (in Russian)

Kövecses, Z. (2018). Metaphor in media language and cognition: A perspective from conceptual metaphor theory. In Lege artis. Language yesterday, today, tomorrow. The journal of University of SS Cyril and Methodius in Trnava. Warsaw: De Gruyter Open, 2018, III (1), June 2018, p. 124-141. DOI: 10.2478/lart-2018-0004 ISSN 2453-8035

Kravtsova, Yu. V. (2014). Metaforicheskoe modelirovanie mira v khudozhestvennom tekste: semantiko-kognitivnyy analiz: monografyja (Metaphorical modeling of the world in artistic text: semantic and cognitive analysis: monograph). Izd-vo NPU im. M. P. Dragomanova. (in Russian)

Lakoff, G., Johnson, M. (2003). Metaphors We Live by. Chicago: The University of Chicago press. 276.

Lakoff, G. (1993). The contemporary theory of metaphor. In A. Ortony (Ed.), Metaphor and Thought (second edition) (pp. 202-251). Cambridge: Cambridge University Press

Mounce, W. (2009). Mounce's complete expository dictionary of old and new testament words. Grand Rapids, Mich.: Zondervan.

Ryken, L., Wilhoit, J., Longman, T., Duriez, C., Penney, D., \& Reid, D. G. (1998). Dictionary of biblical imagery. Downers Grove, Ill: InterVarsity Press. 
Steen, Gerard. (2011). The contemporary theory of metaphor - now new and improved! Review of Cognitive Linguistics, 9 (1), 26-64. DOI:10.1075/ml.9.1.03ste

Strong, J. (1996). The new Strong's complete dictionary of Bible words. Thomas Nelson.

The Orthodox Study Bible. The St. Athanasius Academy of Orthodox Theology (2008). Nashville, TN: Thomas Nelson.

Vorkachev S.G. (2011). Rossiyskaya lingvokulturnaya kontseptologiya: sovremennoe sostoyanie, problemy, vektor razvitiya (Russian linguo-cultural conceptology: present condition, problems, vectors of development). Izvestiya RAN. Seriya literatury i yazyka, Vol. 70 (5), 64-74. (in Russian) 